\title{
PROLOGUE TO THE ENGLISH EDITION
}

Any scholar who has conducted research on Cuba knows how difficult it is to travel to the island and what a great challenge it is to do fieldwork once there, given the difficult economic and political conditions present in the country. Policies of both the U.S. and Cuban governments limit access to such basic means of communication as the telephone, the mail, and the electronic media. Under such circumstances, it was a major accomplishment to be able to write a book that deals in part with present-day Cuban culture.

This book belongs to the corpus of studies about the history of universal reading. I do not mention books banned by the Cuban government, since this study deals with actual public readings in state-controlled cigar factories; I have assumed that such books are never read to the workers. They should be part of a broader study about censorship, a topic that is beyond the scope of my book.

In June 2007, two months after the book was published in Spanish, I presented some of my findings in a number of places in Cuba, among them Casa de las Américas. I took the opportunity then to attend the Fifth International Conference on Culture and Development, where I delivered a talk about libraries and reading aloud in cigar factories. The audience was made up of librarians from all over the world-including many from the United States-and UNESCO's reading advocates. I noted that I felt it was necessary to study reading aloud in prisons and hospitals as it is practiced today. The idea was received very enthusiastically.

The Spanish-language version of the book has already served as an inspiration for some. In the Dominican Republic, for instance, a school for underprivileged children has opened in which reading aloud is practiced, and in Brazil and Nicaragua, consideration is being given to implementing reading aloud in some cigar factories. In Guadalajara, Mexico, cultural 
promoters began conducting seminars on reading aloud intended for both specialists and the general public, and in Cuba, this book is already part of the curriculum for cigar factory lectores. After a lecture I gave at Barnard College, a student decided to go to Bolivia to implement reading in some handicraft workshops in that country. When I began, I never imagined that this study would have such far-reaching implications.

Peaceful Lake Guadalupe is situated on the northern outskirts of Mexico City. The lake is an idyllic place for residents of the capital. Beautiful trees surround it and take people away from the noise of the city. My father lived for a time in a nursing home on the shores of the lake. On one of my visits to see him, I took him a copy of El lector de tabaquería in the hopes that one day he might read it. My father suffered from severe depression caused by the medications he took for a heart condition. He spent hours every day lying in bed or sitting in a chair, staring off into space, having neither the strength nor the will to do anything.

One day when I called him, he said that his doctor wanted to speak with me. My heart started pounding. The doctor told me that he had started reading my book to my father. "I've always read to my patients, because to them, time seems to pass very slowly," he added. To me, that was nothing short of a true revelation. Two months later, on October 23, 2007, my father died.

My book was the last one read to him. 